\title{
A Study of Factors Influencing Organic Product on Health and Environment in Hisar
}

\author{
Manju Loura, Sunita Mehla and Suman Ghalawat* \\ Department of Business Management, CCS Haryana Agricultural University, Hisar, \\ Haryana, India \\ *Corresponding author
}

\section{A B S T R A C T}

Organic products are nothing but the produce grown from beginning to end by means of

Keywords

Modus operandi,

Genetically modified

organism, Naturally

processed and Cronbach

alpha

Article Info

Accepted:

10 September 2018

Available Online:

10 October 2018 environment agreeable modus operandi i.e. devoid of pesticides, exclusive of chemical treatments, free from genetically modified organism, purely and naturally processed. The study focused to study to identify the factors influencing organic products on human and environment. In this paper factor analysis has been used to achieve the objective of the study. In the study, primary data has been collected with the help of semi-structured questionnaire from 200 respondents from Hisar district of Haryana. The factor analysis reveals six factors which are named as environment friendly, perception, hurdles, awareness and manufacturing. Environment friendly, perception and hurdles factors are of utmost importance and Companies need to focus on these factors to capture more market for organic products. The Cronbach alpha value for these factors is relatively high i.e. $0.802,0.770$ and 0.778 . Hence it can be concluded that Government should give more subsidies to the organic product manufacturer so that mass production and variety is possible.

\section{Introduction}

The production and consumption of organic food is on the rise during the preceding decade throughout the world. The outlook and approach for willingness headed for organic food among consumers is undoubtedly on the increase. Suprapto and Wijaya (2012) documented that healthy eating is a good predictor to convince the purchasing intent for organic food. Krissoff (1998) have established that customers like to purchase organic products for the reason that such produce are safe, healthy and environmentally affable.
Organic products are nothing but the produce grown from beginning to end by means of environment agreeable modus operandi i.e. devoid of pesticides, exclusive of chemical treatments, free from genetically modified organism, purely and naturally processed.

These products should encompass organic certificates by the recognized regulatory authority. According to Makatouni (2002) product quality embracing nutritive worth, savour, cleanness, freshness, appearance plus other sensory features control the preferences of end users for organic food products. 
The consumption of organic food is too growing in India. Despite the fact that nearly half of the organic food production in India is marked for exports, but scores of high profile customers have started the purchasing of organic food for domestic consumption. According to Manaloor et al., (2016), in India, the organic food industry is in the premature phase of development.

High disposable earnings and greater health consciousness have directed people towards demand for superior food. Moreover, the organic products in India are usually exported or marketed for prosperous, wealthy and health conscious domestic consumers since there is enormous premium in the trade of organic products.

The most widely used products and commodities in India consists of herbal tea, coffee, organic rice, wheat, among spices it includes cardamom, cinnamon, black pepper, white pepper, ginger, clove, nutmeg, mace, vanilla, mustard, tamarind, turmeric, chilli and the oil seeds of sesame, castor, sunflower etc.

The foremost market investigative firm, ACNielsen, investigated and examined almost 21,000 regular internet customers from 38 countries to reveal their inclination for foods that have added wellbeing benefits on health. The study confirmed that India stands in top ten countries where the customers insist and demand organic food. Other researchers have also documented that the majority of consumers identified organically grown and processed food products as safer or less risky when compared to conventionally grown food (Williams \& Hammitt, 2002). The present study aspires to investigate the impact of organic products on health and environment by the customers residing in Hisar city of Haryana. In addition, the paper strives to observe the awareness and perception among customers towards organic foods.
Shafie and Rennie (2009) examined consumers' insight towards organic products and found that the high prices persist to hold back the consumption of organic food. Although, it is difficult to quantify the health benefits of organic products compared to their justification for premium prices. Stolz (2010) attempted to assess the approach of consumers towards organic and conventional food products. The findings confirmed that the organic consumers have diverse likings. A few are not as much of price sensitive and hold up the use of organic products whereas others are price susceptible and relatively have a preference for conventional products. Gogia (2012) studied the factors leading to acceptance of green products for the sustainability of environment. The paper gauged the level of awareness among consumers in relation to the environment, accessibility of green products in the market and also the approach of consumers to incorporate green products in their buying behaviour. According to Mehra and Ratna (2014) there were six important factors i.e. awareness for organic food, health realization, product knowledge, price worth, ease of access and reliance that influence the consumers' mind-set towards organic food. The study was done with conclusion that females and younger customers perceived positive outlook in support of organic food and also believed that its consumption would be healthier. Women, while deciding about nutrition in food products, were found to be more enthusiastic on comparing product information and labels. Laheri and Arya, (2015) examined the difficulties faced by the customers with regard to organic food. They found that the ease of access and price of the organic products are the leading blockades towards their procurement. Accordingly, the researchers suggested that the traders must initiate to find ways and means to rise above these impediments. Pandurangarao et al., (2017) documented the factors i.e. brand, 
health apprehensions, environment issues, brand promotion, safe product, accessibility, realistically priced, freshness and store location as controlling factors to purchase organic food. The analytical result put on view that health apprehensions, environment issues and safe products were the major influencers.

\section{Objectives of the Study}

To identify the factors influencing organic products on health and environment.

\section{Materials and Methods}

\section{Participants}

Mix blend of Service (80), Business (46) and students (74) from Hisar.

\section{Instrument if any used}

Semi structured Questionnaire was used in the study. The data has already been tested through pilot survey on $10 \%$ of the total sample i.e. 20 respondents to check out the adequacy of the questionnaire and necessary changes have been made afterwards.

\section{Statistical analysis}

Factor analysis was used for investigating the impact of organic products on health and environment and frequency distribution has been used to study the demographic profile of respondents

\section{Procedure}

The data has been collected through primary data from college students from Hisar city from Jan 2018-April 2018. The sample size was 200 respondents from Hisar. The study was based on the semi structured questionnaire consist of 19 statements based on Likert scale ranging from $1=$ Strongly
Disagree to $5=$ Strongly Agree. To analyze the data SPSS 13 has been used. Questionnaire was filled up from a mix blend of doctorate (6), Post Graduate (74), Graduate (70) and undergraduate (50). Finally data was analysed with the help of Factor analysis to reach at the conclusion.

Present study is an empirical research to identify the factors influencing organic products on human and environment. The study is based on the sample of 200 respondents from Hisar district of Haryana state. Convenient sampling method is adopted for collecting the sample. The questionnaire is designed with two sections: section 1 captures demographic information for the purpose of describing the sample and it consist of questions pertaining to age, gender, marital status, educational qualification, employment status, and monthly income. Section 2 has statements relating to the impact of organic product on human and environment. All the 19 statements from section 2 of the questionnaire used a Likert scale ranging from $1=$ Strongly Disagree to $5=$ Strongly Agree. The data is analyzed using SPSS version 13.0. The study employs factor analysis to determine the factors that are considered important while purchasing organic product. Secondary data is collected through research papers, journals, websites and books.

The demographic characteristics of the respondents are summarized in Table 1. It is evident from the Table that the respondents have a relatively greater proportion of males (58 \%) as compared to females (42\%). The sample customers are mostly in the age group of 18-40 years (54\%) followed by age group of more than $41-55$ years $(26 \%)$. Further, a majority of the respondents $(58 \%)$ were married. The respondents were post-graduates (37\%) followed by graduates $(35 \%)$ implying that sample comprises of literate respondents. With regard to the employment status, service 
and students have $(77 \%)$ share implying that respondents are young and dynamic. The table also depicts that $38 \%$ of respondents have income from Rs50000 \& more, whereas 36\% have income upto Rs25000-50000.

\section{Results and Discussion}

In the present study, the researcher applied Kaiser-Meyer-Olkin (KMO) test and Bartlett's Test of Sphericity as pre-analysis verification for judging the suitability of the entire sample which is a pre-requisite of factor analysis. Table 2, shows the value of Kaiser-MeyerOlkin (KMO) and the Bartlett's Test of Sphericity as 0.535 and 2954.261 respectively, which are statistically significant at $1 \%$ level of significance.

Thus, it shows that the sample is suitable for factor analysis. Table 3 presents the overall reliability of this construct with Cronbach's coefficient alpha having the value of 0.743 , which is highly significant.

\section{Factor analysis}

The survey data from the questionnaire is analysed using factor analysis in order to summarize the 19 statements related to impact of organic product into smaller sets. These 19 statements are reduced to six principal components through varimax rotation. Only those factors are considered as significant, whose Eigen-values are more than one. The reliability coefficients for six factors ranged from 0.528 to 0.802 (Table 5) indicating a fair to good internal consistency among the items of each dimensions. Six factors have been extracted which accounts for 78.21 percent of variance. The percentages of variance explained by factor 1 to 6 are 28.36, 14.61, $11.68,9.88,6.86$ and 6.80 percent respectively (Table 4).

The names of the factor statements and factor loadings have been summarized in Table 5.

Further, the six factors that defined these characteristics have been assigned suitable names according to the nature of variables loaded on each factor. The six factors are: environment friendly, perception, hurdles, awareness and manufacturing. Each of these factors is discussed below:

\section{Factor-1: Environment friendly}

The first factor explained highest variance of $28.36 \%$. Six statements related to environment friendly are loaded to this factor. The factor has been named environment friendly as, it consists of statements like: pay even extra price for environment friendly products to save our environment, production of organic products is totally environment friendly, ethical issue, using organic products gives a sense of satisfaction, prefer companies which are having environmental certification and organic products and inorganic products are alike. Respondents in this study likes to prefer environment friendly products i.e. organic products because it will save environment, gives satisfaction as it helps in improving health as well. Thus, the loaded statement to this factor directs us to conclude that the sample respondent's orientation is health and environment.

\section{Factor-2: Perception}

This factor got $14.61 \%$ of the variance, tends to reached second most important. Five statements load high on to this factor. The factor includes statements such as, want to be a part of organic movement by using organic products, prefer organic products over non organic products, Organic products can contribute in better health, Accessibility/reach, prefer buying organic products when price discounts are offered. 
Table.1 Demographic profile of the respondents

\begin{tabular}{|c|c|c|c|}
\hline S. No. & Demographic Profile & Frequency & Percent \\
\hline \multirow[t]{2}{*}{ Sex } & Married & 116 & 58.0 \\
\hline & Unmarried & 84 & 42.0 \\
\hline \multirow[t]{4}{*}{ Age } & 18-25 year & 78 & 39.0 \\
\hline & 26-40 year & 56 & 28.0 \\
\hline & 41-55 year & 52 & 26.0 \\
\hline & $56 \&$ above & 14 & 7.0 \\
\hline \multirow[t]{2}{*}{ Marital Status } & Married & 116 & 58.0 \\
\hline & Unmarried & 84 & 42.0 \\
\hline \multirow[t]{4}{*}{ Education Level } & Under graduate & 50 & 25.0 \\
\hline & Graduate & 74 & 37.0 \\
\hline & Post graduate & 70 & 35.0 \\
\hline & Doctorate & 6 & 3.0 \\
\hline \multirow[t]{3}{*}{ Employment Status } & In service & 80 & 40.0 \\
\hline & Own Business & 46 & 23.0 \\
\hline & Student & 74 & 37.0 \\
\hline \multirow[t]{4}{*}{ Monthly Income } & Less than 10000 & 72 & 36.0 \\
\hline & $10001-25000$ & 22 & 11.0 \\
\hline & $25001-50000$ & 30 & 15.0 \\
\hline & $50001 \&$ more & 76 & 38.0 \\
\hline
\end{tabular}

Table.2 KMO and Bartlett's test

\begin{tabular}{|l|l|l|}
$\begin{array}{l}\text { Kaiser-Meyer-Olkin } \\
\text { Adequacy }\end{array}$ & Measure of Sampling & $\mathbf{0 . 5 3 5}$ \\
\hline $\begin{array}{l}\text { Bartlett's Test of } \\
\text { Sphericity }\end{array}$ & Approx. Chi-Square & 2954.261 \\
\hline & df & 171 \\
\hline & Sig. & 0.000 \\
\hline
\end{tabular}

Table.3 Reliability statistics

\begin{tabular}{|l|l|}
\hline Cronbach's Alpha & 0.743 \\
\hline No. of Items & 19 \\
\hline
\end{tabular}

Table.4 Total variance explained

\begin{tabular}{|l|l|l|l|l|l|l|}
\hline & Factor 1 & Factor 2 & Factor 3 & Factor 4 & Factor 5 & Factor 6 \\
\hline Eigen Values & 5.38 & 2.77 & 2.22 & 1.87 & 1.30 & $\mathbf{1 . 2 9}$ \\
\hline \% of Variance & 28.36 & 14.61 & 11.68 & 9.88 & 6.86 & $\mathbf{6 . 8 0}$ \\
\hline Total & $\mathbf{2 8 . 3 6}$ & $\mathbf{4 2 . 9 7}$ & $\mathbf{5 4 . 6 6}$ & $\mathbf{6 4 . 5 4}$ & $\mathbf{7 1 . 4 1}$ & $\mathbf{7 8 . 2 1}$ \\
\hline
\end{tabular}


Table.5 Factor names and their loadings

\begin{tabular}{|c|c|c|c|c|}
\hline $\begin{array}{l}\text { S. } \\
\text { No. }\end{array}$ & Factors & Statements & $\begin{array}{l}\text { Eigen } \\
\text { Value }\end{array}$ & $\begin{array}{l}\text { Cronbach } \\
\text { alpha }\end{array}$ \\
\hline 1. & \multirow[t]{6}{*}{$\begin{array}{l}\text { Environment } \\
\text { friendly(F1) }\end{array}$} & $\begin{array}{l}\text { I would agree to pay even extra price for } \\
\text { environment friendly products to save our } \\
\text { environment. }\end{array}$ & .841 & \multirow[t]{6}{*}{.802} \\
\hline 2. & & $\begin{array}{l}\text { Production of organic products is totally environment } \\
\text { friendly. }\end{array}$ & .761 & \\
\hline 3. & & Ethical issue & .748 & \\
\hline 4. & & Using organic products gives a sense of satisfaction. & .656 & \\
\hline 5. & & $\begin{array}{l}\text { I prefer companies which are having environmental } \\
\text { certification }\end{array}$ & .250 & \\
\hline 6. & & Organic products and inorganic products are alike. & .549 & \\
\hline 7. & \multirow[t]{5}{*}{ Perception (F2) } & $\begin{array}{l}\text { I want to be a part of organic movement by using } \\
\text { organic products. }\end{array}$ & .903 & \multirow[t]{5}{*}{.770} \\
\hline 8. & & I prefer organic products over non organic products. & .822 & \\
\hline 9. & & Organic products can contribute in better health. & .658 & \\
\hline 10. & & Accessibility/reach & .624 & \\
\hline 11. & & $\begin{array}{l}\text { I prefer buying organic products when price } \\
\text { discounts are offered. }\end{array}$ & .316 & \\
\hline 12. & \multirow[t]{2}{*}{ Hurdles(F3) } & Less awareness & .760 & \multirow[t]{2}{*}{.778} \\
\hline 13. & & Prices are higher & .718 & \\
\hline 14. & \multirow[t]{3}{*}{ Awareness (F4) } & $\begin{array}{l}\text { I use organic products because I want to protect my } \\
\text { family members. }\end{array}$ & .874 & \multirow[t]{3}{*}{.528} \\
\hline 15. & & $\begin{array}{l}\text { While purchasing an organic product, one should } \\
\text { spend enough time to read the label in order to ensure } \\
\text { that the contents of the product are actually organic. }\end{array}$ & .721 & \\
\hline 16. & & $\begin{array}{l}\text { There must be some certification which confirms that } \\
\text { the product is organic }\end{array}$ & .422 & \\
\hline 17. & \multirow[t]{2}{*}{$\begin{array}{l}\text { Manufacturing } \\
\text { (F5) }\end{array}$} & $\begin{array}{l}\text { Manufacturing of organic products must be highly } \\
\text { subsidized so that more companies can enter into } \\
\text { manufacturing of organic products. }\end{array}$ & .784 & \multirow[t]{3}{*}{.667} \\
\hline 18. & & Less variety of organic products & .682 & \\
\hline 19. & Authenticity (F6) & Authenticity to be organic or not & .804 & \\
\hline
\end{tabular}

The factor has been named as perception as the statements belonging to this factor reveal that some time perception of the customer will help out in taking decision. Perception towards organic movement makes the masses associated and prefers organic products. Hence it can be concluded that in near future organic products will be used by masses over non-organic products.

\section{Factor-3: Hurdles}

It is also considered as significant and accounts for $11.68 \%$ of the variance. This factor loaded two features, has been named as hurdles. The factor incorporates the statements such as less awareness and prices are higher. This factor has been named as hurdles, the reason for this can be lack of 
awareness among customers and moreover, prices of organic products are higher as compared to non-organic products. Due to high prices, organic products are not preferred by the low income customers. Hence it can be concluded that, companies should organise more awareness campaigns and cost should be cut down to increase the market size.

\section{Factor-4: Awareness}

The fourth factor that surfaced from the factor analysis accounts for $9.88 \%$ of the variations and has been designated as Awareness. Eigen value of 1.87 indicated that this factor is of moderate significance to the respondents. The three statements incorporated on this factor are: use organic products because $i$ want to protect my family members, While purchasing an organic product, one should spend enough time to read the label in order to ensure that the contents of the product are actually organic, there must be some certification which confirms that the product is organic. This factor shows that customer get awareness through labels and certification of the organic products. Hence this can be concluded that customer needs information and if company provides it then only customer purchase it.

\section{Factor-5: Manufacturing}

This factor accounts for $6.86 \%$ of variance, which is of moderate significance. It comprises of two statements. The two integrated statements of this factor incorporate, Manufacturing. Consequently, it is named as manufacturing as two statements have been loaded like manufacturing of organic products must be highly subsidized so that more companies can enter into manufacturing of organic products, less variety of organic products. As manufacturing of organic product is very costly affair and production is very less due to high initial cost.
So variety of organic product is not at all possible. That is why customers have to pay more for organic products.

\section{Factor-6: Authenticity}

This factor accounts for $6.80 \%$ of variance and the corresponding Eigen value is 1.29, that also represent factor is of moderate significance to the respondents. This factor has been named as authenticity; only one statement has been loaded on this factor. Whenever customer is purchasing organic product, he is not sure about its originality and quality. Hence it can be concluded that organic product should carry hologram so that nobody can cheat the customer by copying it. The present study is an effort to investigate the impact of organic products on health and environment and study the demographic profile of respondents of Hisar city, the study provides better insights to the organic product manufacturing administrators for initiating efforts to increase the awareness among customers. As manufacturing of organic product is very costly affair and production is very less due to high initial cost. So variety of organic product is not at all possible. That is why customers have to pay more for organic products. This result agrees with the findings of Mondelaers et al., and Enneking, who found that organic consumers are much less price-sensitive compared with non-buyers. Companies should organise more awareness campaigns and cost should be cut down to increase the market size. Organic product should carry hologram so that nobody can cheat the customer by copying it. Hence it can be concluded that in near future organic products will be used by masses over nonorganic products.

\section{References}

Enneking, U., (2002). "Analysis of food preferences using discrete choice 
modelling - the case of organic sausages", Agrarwirtschaft. 52. pp.254 267.

Gogia, J. (2012). Consumer's compliance to adopt Eco-friendly products for environmental sustainability.

International Journal of Research in Commerce and Management.

Krissoff, B., 1998. Emergence of U.S. organic agriculture - can we compete? American Journal of Agricultural Economics. 80(5): 1130-1133.

Laheri VK, Arya PK. A Study on Consumer Decision towards Purchase of Organic Food Products: A Case Study of Delhi. Indian Journal of Commerce \& Management Studies. 2015; 6(2):84-87.

Makatouni, A., (2002) What motivates consumers to buy organic food in UK? Results from a qualitative study. British Food Journal. 104(3/4/5): 345-352.

Manaloor V, Srivastava D, Islam S. 2016 Growth of Organic Food Industry in India. AGROFOR International Journal. 1(2):69-76.

Mehra S, Ratna PA. (2014) Attitude and behavior of consumers towards organic food: an exploratory study in India. International Journal of Business Excellence; 7(6):677-696.

Mondelaers, K., W. Verbecke, G. Van Huylenbroeck. (2008). "Importance of health and environment as quality traits in the buying decision of organic products". in: Proceedings of the First Workshop on Valuation Methods in Agro-food and Environmental Economics. Barcelona.

Pandurangarao D, Chiranjeevi K, Rao DS. Factors Affecting Consumers to Buy Organic Food Products in Hyderabad and Secunderabad. International Journal of Business and Management Invention. 6(3), 24-30.

Shafie, F., \& Rennie, D. (2009). Consumer perception towards organic products. Procedia- Social and Behavioural Sciences, 360-367.

Stolz, H., Stolze, M., Hamm, U., Janssen, M., \& Ruto, E. (2010). Consumer attitude towards organic versus conventional food with specific quality attributes. Wageningen Journal of Life Sciences, 67-72.

Suprapto Budi and Wijaya Tony 2012 Intentions of Indonesian Consumers on Buying Organic Food International Journal of Trade, Economics and Finance, Vol. 3, No. 2, pp114-119.

Williams, P. and J. Hammitt. 2001. Perceived Risks of Conventional and Organic Produce: Pesticides, Pathogens, and Natural Toxins. Risk Analysis 21: 319330.

\section{How to cite this article:}

Manju Loura, Sunita Mehla and Suman Ghalawat. 2018. A Study of Factors Influencing Organic Product on Health and Environment in Hisar. Int.J.Curr.Microbiol.App.Sci. 7(10): 1025-1032. doi: https://doi.org/10.20546/ijcmas.2018.710.114 